\title{
A new policy for the management of the Kruger National Park's elephant population
}

\author{
I.J. Whyte, H.C. BiggS, A. GaYlaRd and L.E.O. BraACK
}

Whyte, I.J., H.C. Biggs, A. Gaylard and L.E.O. Braack. 1999. A new policy for the management of the Kruger National Park's elephant population. Koedoe 42(1): 111-132. Pretoria. ISSN 0075-6458.

Arising from public debate held in Midrand on 4 May 1995, the South African National Parks undertook to review its policy for the management of elephant in the Kruger National Park. The new policy focuses on the extent and intensity of elephant impacts on biodiversity rather than on numbers of elephants per se, and is based on four fundamental principles: a) That ecosystems are not static; fluctuations of conditions and population responses are an inherent attribute of ecosystems and contribute to biodiversity. A range of elephant impacts in different areas at different times, is thus also natural and desirable; b) That elephants are important agents of habitat modification and thus contribute to biodiversity (intermediate disturbance hypothesis); c) That elephant populations which are confined will increase in number until negative impacts on the system's biodiversity will ultimately result; d) That elephants should not be viewed in isolation, but as one component of a broader, integrated system, and their impacts should be managed in conjunction with other ecosystem process (such as fire) to promote biodiversity in its broadest sense. The new policy proposes that the Kruger National Park be divided into six zones-two botanical reserves, two high-elephant-impact zones (no population reduction) and two low-elephant-impact zones (where numbers will be actively reduced). A history of the elephant population is given, and a resumè of previous policies.

Key words: elephants, elephant management, culling, heterogeneity, biodiversity, Kruger National Park.

I.J. Whyte, H.C. Biggs and L.E.O. Braack, Conservation Development, Private Bag X402, Skukuza, Kruger National Park, 1350 Republic of South Africa; A. Gaylard, Department of Biology, University of the Witwatersrand, Johannesburg, Republic of South Africa.

\section{Introduction}

Although a broad cross section of the South African public had come to accept the reasons proposed by earlier managers for the necessity of culling elephants in the Kruger National Park (KNP) which was initiated in 1967 , this policy has always been somewhat controversial. In late 1994 the issue was again debated when the reasons for culling and the ethical morality of killing elephants were raised by certain animal rights groups. This resulted in a public debate being held in Midrand on 4 May 1995, at which South African National Parks (SANP) undertook to review its policy for the management of elephant in the KNP. In accordance with this undertaking, a series of meetings and workshops were held in order to reconsider the policy and make recommendations on appropriate management for the future. Though 
the authors were responsible for the write-up of this policy, it is the product of many hours of consultative debate between SANP and a wide diversity of interested and affected people and organisations.

\section{The processes followed}

The first of these workshops was held in Skukuza on 8 February 1996 in conjunction with members of the African Elephant Specialist Group (AfESG). This was followed up by a meeting two days later with delegates of the AfESG and the International Fund for Animal Welfare (IFAW). The new rationale was summarised in a document prepared by Hall-Martin \& Novellie (1996).

On 30 October 1996 at a workshop held in Skukuza, a wide-ranging series of possible management options were listed and debated. The results of this meeting were reported on by Whyte \& Biggs (1997). The options debated were:

A the previous management policy was just about right;

$\mathrm{B}$ there are too many elephants;

C there are too few elephants;

D1 the KNP ecosystem needs natural fluctuations of elephants;

D2 the KNP ecosystem needs controlled fluctuations of elephants;

E “animal rights" (laissez-faire) type of policy (no culling);

F community involvement/sustainable consumptive utilisation;

$\mathrm{G}$ maximising economic opportunities.

The resolutions accepted by this meeting

The National Parks Board mandate and primary responsibility within the KNP was to conserve all elements of biodiversity and not to manage selectively for the benefit of a single species such as elephant. Elephants are not more important than any other componen, although they are important and major ecosystem components.
Wildlife populations do not remain static through time and space, and consequently elephants should not be maintained at a stable unvarying population ceiling, but rather that fluctuation in numbers and density should be introduced to simulate ecosystem processes and enhance biodiversity

In contrast with all other known animal species, elephant (and possibly rhino) do not respond to short-term climatic cycles so that, in recognition of the negative impact unimpeded population growth would have on other wildlife in an unnaturally limited "conservation island", some form of population control would be necessary for elephant (and perhaps eventually rhino)

There is evidence of severe impact by elephant at current densities in certain areas of the park so that such areas may already have reached threshold levels of elephant density.

The implication therefore was that Option D2 would be how the elephant population management issue should be approached in future. There was consensus that the consequences of unrestricted elephant population growth resulting in an ultimate self-induced population crash are not acceptable.

These resolutions were presented to the public during the debate held at Midrand on 12 November 1996. Very little comment was voiced by the meeting participants, either to these resolutions or the Hall-Martin \& Novellie (1996) document, which was then accepted by the SANP as a mandate to proceed with defining the detail of this new policy proposal.

The first step in doing this was the convening of a workshop to discuss the maintenance of biodiversity in the KNP. A wide variety of scientific expertise both nationally and internationally was invited to attend and participate in this workshop which was held between 11-13 February 1997. The focus of the workshop was to develop means for the determination of "Thresholds of Potential 
Concern"-also known as "Limits of Acceptable Change". TPCs can defined as those upper and lower levels along a continuum of change in a selected environmental indicator which, when reached, prompts an assessment of the causes which led to such an extent of change, and results in either:

- management action to moderate such cause(s), or

- re-calibration of the threshold to a more realistic or meaningful level.

The new policy recommendation, as described here, was then formulated at a final meeting of National Parks Board staff held in Skukuza on 17 March 1997.

The finalised policy document was presented on the internet for further public scrutiny, and on 31 October 1998 was also presented at a public meeting convened in Nelspruit. Almost unanimous public support was given at this meeting, the only objection coming from the animal rights group FALCON who felt that at least another 10 years was necessary before implementation, as new technologies may be forthcoming (such as contraception) to solve the problem in non-lethal ways (South African National Parks 1998). As there is no guarantee of this, and acknowledging the support of the majority of the people and organisations represented, the SANP Board approved the policy on 12 March 1999.

\section{Theoretical basis of the new policy}

The KNP is committed to a mission emphasising biodiversity in the widest sense (i.e. structure, function and composition across scales from genetic to landscape and even subcontinental), and makes specific mention of fluxes as part of this. The theoretical basis of quantifying and managing for biodiversity and flux has its origin in the emergent heterogeneity paradigm (e.g. Christensen 1997; Fiedler et al. 1997), but still has many unknown dimensions in practice.
Driving variables in savannas include nutrients, moisture, fire, herbivory and others. Elephant herbivory is considered particularly significant as in some studies, elephants at high densities have been shown to negatively affect biodiversity (Cumming et al. 1997; Western \& Gichohi 1989). If there is variation in these driving variables over time and space, an ever-changing mosaic should be the outcome. The patches which result are seen as organised in a hierarchy of scales (Wiens 1997). If many levels of (say) herbivory are naturally superimposed on, for example, a fire mosaic, then at certain scales even more diversity should result. The intermediate disturbance hypothesis claims that the greatest species richness (and perhaps overall biodiversity) at one point in time and space is likely to result from intermediate levels of disturbance. At extreme levels of both low and high disturbance, there might indeed be fewer species, but there should very likely exist certain species which are not favoured or are even absent at intermediate levels. Thus, if the ecosystem can pass through various stages of disturbance in different places and at different times, the patchwork created might support the greatest overall diversity desirable in a natural system, though spatial variation can in many ways substitute for temporal variation and vice versa.

An equally important issue is the rate of change, as influenced by the pattern and intensity of disturbance - a rapidly-increasing disturbance regime often has different ecological effects to a slowly-increasing one, even if the final intensity is the same.

In recent years there has been increasing belief that most of the important changes in savannas are event-driven. They may occur only occasionally, when a certain co-occurrence of events (perhaps drought plus rapidly-rising levels of herbivory plus fire at a critical period, followed by good rain) brings about a particular shift from one state to another (perhaps an invasion of bush into grassland). Different ecological pressures then prevail which may stabilise the system 
in a new state for years or even decades. Current ecosystem theory takes cognisance of the likelihood of the existence of multiple stable states (Dublin 1995) as well as considering several other models of ecosystem dynamics. These differing ideas about how systems function span a range from the classical homogeneity / stability paradigms through to the relatively revolutionary disequilibrial notions (Behnke et al. 1993). Each of these models appears to have had some validity at some location and scale over some time span, our current understanding falling short of integration of these into a unified theory. Holling (1995) and others assert that by finding a particular apparent "winning recipe for ecosystem management" at a locality (the more homogeneous, seemingly the more dangerous) and keeping it static for too long, invariably leads to catastrophic change when an extreme event occurs, usually because of lack of resilience.

Scaling is an historically underrated issue and its understanding forms the crux of much new insight. Elephant impacts may operate at various scales, and much of what is presented here assumes that animals with such large body sizes, home ranges, walking ability and propensity for fast increase are likely to create landscape-scale effects. Equally they may, perhaps at lower densities, create a mosaic of medium-scale (hundreds of metres to $10 \mathrm{~km}$ ) effects, e.g., with patches of riverine vegetation being "stripped completely" and other patches nearby not being touched. At the individual tree level, different fine-scale sequelae of their feeding on some parts and not others of the tree, might lead to habitat diversity for different insects. Time scales are equally important: long-term views often places shorter-term fluctuations into the perspective of making up the natural flux.

What does all this mean for management? Managers of natural systems are now entering an era where heterogeneity needs not only to be understood, but also implemented in some practical way. The outcome of this elephant management strategy is an attempt to meet this challenge, even if the scales at which the processes occur needs further understanding. The belief is, in the first place, that this management strategy will enhance biodiversity. Secondly, at the same time, it will provide an opportunity to learn by managing, a crucial element of adaptive management. Although much use will be made of the outcomes to learn more about future elephant management, it should not be seen primarily as an experiment-the options chosen are genuinely intended to meet the primary biodiversity objective of the KNP, rather than constitute any contrived or forceful experiment. Obviously, "unnatural over-heterogenisation" is possible, and is indeed practised by smaller ecotourism operations specifically to create habitat diversity for more species than might naturally occur at these sites. It is not the intention of the SANP to take the management of the KNP to this unnatural level, indeed where this has happened (artificial waterholes can lead to heterogenisation or homogenisation, obviously depending on the context) it is being reversed. In the same vein, the SANP would like to vary rates of change (thus increasing diversity, also through the differential resilience of different species and systems to different rates) but in a natural regime. The word "natural", as also embodied in the mission statement, thus provides an important cornerstone of this action. The TPCs, which will be continuously refined as knowledge, experience and hopefully wisdom grow, provide an attempt to outline the "envelopes" of acceptability to management. They are meant to delineate thresholds beyond which it is believed to the system will have exceeded its inherent elasticity, and from which it may not have the ability to return to a healthy state.

The occurrence of the kinds of events which bring about changes, even drastic-seeming changes, should not be suppressed if they are natural, as they may contribute significantly to system resilience in the long-run (Holling 1995). Park management should thus be geared to allowing these to take place. Management has to be capable of tracking 
ecosystem changes to see that they fall within TPCs, and may need to nudge the system in the "correct" direction if it is predicted with a degree of certainty that sustained trajectories will exceed TPC's. More drastic intervention may be needed when gross overshoot of TPCs has taken place due to modern human influence, though if the adaptive management and TPC-monitoring system works well, this may not often be necessary. Understanding of the scales at which these different processes related to elephant impact occur, is an awesome task, and will demand much research and modelling. Certainly, the SANP is trying to adopt a longer-term view, though realising the importance of perhaps shorter-term considerations such as the immediate tourism value of this unique species, as well as moral and ethical considerations.

\section{History of the KNP elephant population}

In order to put the new policy for the management of the elephant population of the Kruger National Park (KNP) into perspective, a brief account of the history of the population and the evolution of the previous management policy are given. This was derived from more detailed accounts of the history of the KNP elephant population (Whyte 1997).

The Sabi Game Reserve was initially proclaimed in 1898, and Colonel James Stevenson-Hamilton arrived as first resident Warden of the Sabi Game Reserve in July 1902. His initial conclusion was that there were no elephants (Stevenson-Hamilton 1903a, 1903b). By 1905, spoor had been found of a few elephants near the confluence of the Letaba and Olifants rivers (StevensonHamilton 1905) after which a steady increase in numbers was noted.

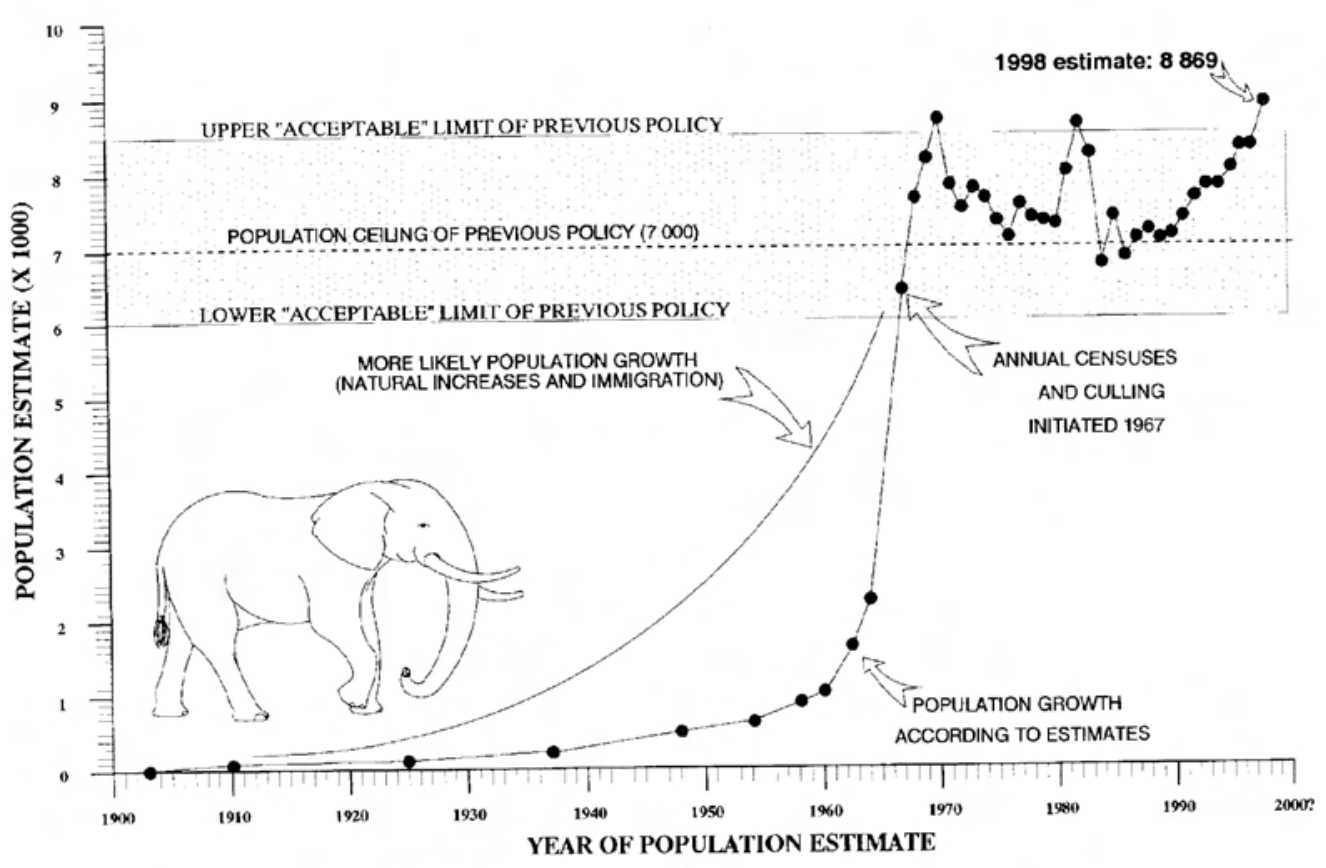

Fig. I. Kruger National Park elephant population trends between 1903 and 1998. 
Table 1

Estimates of numbers of elephants in the Kruger National Park between 1903-1995

\begin{tabular}{|c|c|c|c|}
\hline Year & Number & Nature of estimate & \\
\hline 1903 & 0 & Estimate & Stevenson-Hamilton 1903a, 1903b \\
\hline 1905 & 10 & Estimate & Stevenson-Hamilton 1905 \\
\hline 1908 & 25 & Estimate & Stevenson-Hamilton 1909b \\
\hline 1925 & 100 & Estimate & Stevenson-Hamilton 1925 \\
\hline 1931 & 135 & Estimate & c.f. Pienaar, van Wyk \& Fairall 1966 \\
\hline 1932 & 170 & Estimate & Stevenson-Hamilton 1932 \\
\hline 1933 & 200 & Estimate & Stevenson-Hamilton 1933 \\
\hline 1936 & 250 & Estimate & Stevenson-Hamilton 1936 \\
\hline 1937 & 400 & Estimate & Stevenson-Hamilton 1937 \\
\hline 1946 & 450 & Estimate & Sandenberg 1946 \\
\hline 1947 & 560 & Estimate & c.f. Pienaar, van Wyk \& Fairall 1966 \\
\hline 1954 & 740 & Estimate & Steyn 1958 \\
\hline 1957 & 1000 & Estimate & Steyn 1958 \\
\hline 1960 & 1186 & Aerial survey & c.f. Pienaar, van Wyk \& Fairall 1966 \\
\hline 1962 & 1750 & Fixed-wing survey & Pienaar 1963 \\
\hline 1964 & 2374 & Helicopter count & Pienaar, van Wyk \& Fairall 1966 \\
\hline 1967 & 6586 & Helicopter count & Pienaar 1967 \\
\hline 1968 & 7701 & Helicopter count & Pienaar 1968 \\
\hline 1969 & 8312 & Helicopter count & Pienaar 1969 \\
\hline 1970 & 8821 & Helicopter count & Pienaar \& van Wyk 1970 \\
\hline 1971 & 7916 & Helicopter count & Joubert \& Pienaar 1971 \\
\hline 1972 & 7611 & Helicopter count & Joubert \& Pienaar 1972 \\
\hline 1973 & 7965 & Helicopter count & Joubert \& Pienaar 1973 \\
\hline 1974 & 7702 & Helicopter count & Joubert \& Pienaar 1974 \\
\hline 1975 & 7408 & Helicopter count & Joubert \& Pienaar 1975 \\
\hline 1976 & 7257 & Helicopter count & Joubert, et al. 1976 \\
\hline 1977 & 7715 & Helicopter count & Joubert \& Pienaar 1977 \\
\hline 1978 & 7478 & Helicopter count & Joubert \& Pienaar 1978 \\
\hline 1979 & & No census & \\
\hline 1980 & 7454 & Helicopter count & Joubert 1980 \\
\hline 1981 & 7343 & Helicopter count & Joubert 1981 \\
\hline 1982 & 8051 & Helicopter count & Joubert 1982 \\
\hline 1983 & 8678 & Helicopter count & Joubert 1983 \\
\hline 1984 & 8273 & Helicopter count & Joubert 1984 \\
\hline 1985 & 6887 & Helicopter count & Joubert 1985 \\
\hline 1986 & 7617 & Helicopter count & Joubert, Hall-Martin \& Whyte 1986 \\
\hline 1987 & 6898 & Helicopter count & Hall-Martin, Whyte \& Viljoen 1987 \\
\hline 1988 & 7344 & Helicopter count & Whyte \& Viljoen 1988 \\
\hline 1989 & 7468 & Helicopter count & Whyte 1989 \\
\hline 1990 & 7278 & Helicopter count & Whyte 1990 \\
\hline 1991 & 7470 & Helicopter count & Whyte 1992 \\
\hline 1992 & 7632 & Helicopter count & Whyte \& Wood 1993 \\
\hline 1993 & 7834 & Helicopter count & Whyte \& Wood 1994a \\
\hline 1994 & 7806 & Helicopter count & Whyte \& Wood 1994b \\
\hline 1995 & 8064 & Helicopter count & Whyte \& Wood 1995 \\
\hline 1996 & 8320 & Helicopter count & Whyte \& Wood 1996 \\
\hline 1997 & 8371 & Helicopter count & Whyte 1998 \\
\hline 1998 & 8869 & Helicopter count & Whyte 1998 \\
\hline
\end{tabular}


The trend in the population between 1903 and 1998 is shown graphically in Fig. 1 and it is clear from this that the increase between the years 1960 and 1967 cannot be due to biological increase alone. In all likelihood the reported totals prior to 1967 were gross under-estimates and that the first aerial census yielded a result much closer to the actual figure, suggesting a massive increase over the period between 1964 and 1967. It is unlikely that any of the estimates prior to 1967 have any real value compared with the latter ones using aerial census techniques. Another curve has been added to the graph which probably reflects the actual population increase more closely. This would include biological increase as well as immigration from the neighbouring territories-Zimbabwe (then Rhodesia) and Mozambique.

In 1967, annual aerial censusing of the population as well as population control (culling) were initiated. Estimates for the population given in the respective annual reports and census reports up to 1996 are summarised in Table 1 along with the nature of the estimate and the source reference. Fig. 1 shows this data graphically.

\section{The historical evolution of the previous elephant management policy}

It is clear that the question of controlling elephant numbers in the KNP had been discussed among staff as far back as at least the early 1940s. This is illustrated by an amusing excerpt which has been translated here from the diaries of one of the Rangers of the time (Steyn 1942). "With regard to the question of the control (culling) of elephants in certain areas where it may become necessary, the following idea came to mind, i.e. to use a 10 or 12 ton armoured car to remove them from any region. This will naturally only be possible after the present war and I leave the details to the imagination of the reader".

During the 1950s and early 1960s there was a growing feeling among some biologists in Africa that elephant numbers should be con- trolled to prevent habitat change. Beuchner et al. (1963) concluded that in Murchison Falls National Park (Uganda) 4.5-5.5 elephants/mile ${ }^{2}$ was exceeding the carrying capacity and that "their numbers must be regulated to avoid damage to the vegetation and for the future welfare of the population of elephants". Similarly Glover (1963) felt that for Tsavo National Park (Kenya) "one elephant/mile ${ }^{2}$ is apparently the highest stocking rate possible..." and "If the habitat is to be preserved in its present form for all of the animals in the park, then the numbers of elephants will have to be controlled".

These feelings were shared by the KNP's biologists who also felt that it may become necessary to limit elephant population growth in the KNP. This feeling was expressed by Pienaar (1960): "The desirability of elephant control measures on a more general basis, which may become necessary in the near future, is a much more sensitive problem and will only be successfully solved after attention has been paid and information has been acquired regarding the actual numbers of elephant in the South, the number of breeding herds, herd composition, seasonal movements, ... as well as aspects such as how and where control should be applied'. In conclusion, Pienaar (1960) made (among others) the following recommendations regarding the management of the elephant population:-

- that the collection of the information mentioned above be regarded as a matter of urgency - an aerial census was suggested as the best means of obtaining the information;

- that in the light of the above information, an elephant population level be prescribed for the Southern District;

- that all surplus elephants be destroyed annually through culling operationspreferably in the boundary areas and with due respect for outstanding individuals;

- that during normal years, elephants be denied the strip along the Crocodile River as well as a belt along the western boundary; 
- that quantitative culling be applied elsewhere with great caution, if necessary".

On 30 November 1965, a symposium was convened in Pretoria by the National Parks Board of Trustees (hereafter referred to as "the Board") which many South African biologists of the time attended. The symposium focused on "over-protection". Papers delivered at this symposium were on general principles (Knobel 1965), ecological regions of the KNP (Brynard 1965), problem areas (Van Wyk 1965), reproduction and biological control (Fairall 1965), control by diseases and parasites (Van Niekerk 1965), animals, areas and populations; desirability of culling and methods (Pienaar 1965), byproducts (Labuschagne 1965) and publicity (Van der Merwe 1965). The recommendation to the Board emanating from this conference was that population numbers of seven species be artificially controlled by means of culling. The species involved were elephant, buffalo, hippo, giraffe, wildebeest, zebra and impala. At its next meeting the Board decided that the culling of these species should take place (National Parks Board of Curators 1966).

Reporting on the census results of 1964, Pienaar et al. (1966) concluded that "It would appear that theoretically a carrying capacity of 1-4 elephants per square mile, depending on the existing vegetation, available water supplies and size of the area, holds for the majority of elephant habitats in Africa". Following this, Van Wyk \& Fairall (1969), from the results of their research on the impact of elephants on the vegetation of the KNP, recommended that "... the highest number of elephants which could be carried ... would be 0,75/mile (i.e. 6000 elephants) if the total destruction of the vulnerable areas near water is not to result".

Pienaar (1996) also stated that the above recommendations were supported by results obtained during the first helicopter census in 1964, “... 1139 elephants occurred in the Letaba River and its main tributaries (namely the Ngwenyene, Tsende, Shipikane, Makhadzi and Mbyashishe). This was appar- ently the preferred habitat of these animals ... in which they stayed during the recolonisation years until they approached a natural saturation point before they, in ever increasing numbers, began to disperse northward and later southward ... Because the recolonisation of the Letaba-Tsende area, which can be considered as prime elephant habitat, could occur without hindrance or human interference, it must be accepted that the elephant density per unit area during the continuing process of dispersal would give a very good indication of a self-imposed (i.e. natural) saturation level for elephants in this habitat. A planimetric calculation of the area of this original elephant homeland yielded an area of 1030 mile $^{2}$ - that is one elephant per mile ${ }^{2}$.

Based on the various meetings and the research reported by Van Wyk \& Fairall (1969), the then Director of the National Parks Board (Mr Rocco Knobel) recommended to the Board at a meeting held on 17 June, 1968, that the recommendation contained in Annexure "B" of the agenda with respect to the culling of elephant and buffalo in the KNP be adopted. The Annexure read as follows: "Until the water provision program has been finalised in its entirety, both the elephant and buffalo populations of the KNP should be held at their current level...". At this time the latest estimate for the elephant population (1967 census) was 6586 . This recommendation was adopted by the Board. Although it is obscure when or for what reasons it was changed, this figure was later rounded to 7000 .

In 1986 the management plan (Masterplan) for the KNP was completed (Joubert 1986b) and many of the management policies (including those pertaining to the elephant population) were formalised. This Masterplan acknowledged, however, "that policies represent the dynamic aspects of wildlife management and are subject to amendments with the accumulation of information and revised interpretations" and it is the duty of the Standing Committee for Wildlife Management to "revise the Masterplan ... on 
an ongoing basis, i.e. that additions and amendments to policies be recorded where applicable on an annual basis and that such additions/amendments be incorporated in a comprehensively revised Masterplan at fiveyearly intervals and be submitted to the Board'. It is therefore clear that, given information which indicates that current policies are not appropriate, they can be changed at any time. The following are brief, quoted summaries of the relevant principles and policies embodied in the most recent (1993) update:

The National Parks Act: ecosystem preservation-the basic issue

"The concept of ecosystem preservation is well established in nature conservation practice ... and is the primary objective for the proclamation of National Parks as defined in the National Parks Act (1976, as amended).

"This being the highest priority ... and, in fact, the legal responsibility of the Board, ... the preservation of structural and species diversity ... is an inherent part of ecosystem preservation".

Policies applicable to high-density species

"In the case of species whose population cycles extend over ... two or more climatic cycles, and especially where this situation may lead to:

a. artificially high densities due to spatial limitations of the KNP,

b. material changes in either the structure and/or composition of the woody element of the vegetation, and

c. changes in the structure and/or composition of the animal communities which may result in the impoverishment of such communities by affecting their structural and species diversity,

d. the artificial manipulation of such populations is accepted as a realistic and responsible management option".
"The only two known species to fall within this category are elephant and buffalo ... (it has become accepted since the writing of the 1986 Masterplan that buffalo do in fact respond to short-term climatic cycles, as amply illustrated during the severe 1982 and 1992 droughts). In both cases it is accepted, however, that under more natural situations their populations would also reach peaks and troughs and that such changes in population densities form an integral part of the functional aspects of ecosystems. Under the present circumstances it has become virtually impossible to assess the full implications of their ecological role in ecosystems. In spite of this situation it is imperative that special attention be paid to:

- "the accumulation and assessment of data which could be of relevance in evaluating medium and long term population cycles,

- "the influence of the long term maintenance of relatively stable population levels on other components of ecosystem, in particular the vegetation and consequently also the associated animal populations, and

- "the possibility of simulating natural fluctuations in the management of these populations".

"Until such time that the required information is available, the objective continues to be to maintain the elephant population at 7000 ..., but accepting fluctuations between 6000 and $8000 "$

\section{Culling methods}

Between 1967 and 1990, culling was carried out through remote intra-muscular injection (darting) of the compound Scoline (Succinylcholine chloride) from a helicopter. This compound acts as a neuro-muscular blocker, preventing the nervous impulse from the brain reaching the musculature. This induces paralysis, initially of the locomotory muscles, followed by the diaphragm and ultimately also the cardiac muscles. The advantage of this method is that the animals 
are paralysed, guaranteeing the safety of the personnel on the ground. Physiological research showed however that this is not a humane way of killing elephants, as the brain remains unaffected by the scoline and in effect the animal, while fully conscious, suffocates until dead from lack of oxygen.

An attempt was then made to improve the culling method by darting the elephant initially with scoline but then brain-shooting the animal as soon as it became recumbent and before the effects of suffocation would be experienced. In practice, however, this could not always be ensured and some animals could not be shot before suffocation commenced. In an attempt to use only the most humane method, the most recent technique excludes the use of scoline completely, and every animal is brain shot from the helicopter. This has proven satisfactory so far, but the possibility of wounding of the animals remains a concern as this increases the risk to ground personnel.

\section{Current thinking and approach to ele- phant management}

\section{Principles}

The new elephant management policy rests on three fundamental principles on which there was consensus at the meeting of 30 October 1996. These are:

In accordance with the new vision statement of the KNP it is accepted that flux in ecosystems is natural and desirable as this contributes to biodiversity and that this is probably also true for the elephant population.

It is accepted that elephants are important agents of disturbance and as such create heterogeneity and thus contribute to biodiversity (intermediate disturbance hypothesis). This means that in the absence (or very low densities) of elephants, biodiversity will be negatively affected as no disturbance occurs. At excessively high densities, biodiversity will also be negatively affected as the disturbance becomes excessive (these high and low end-points may also be shown to be desirable as it is believed that certain species will benefit from the conditions thus created, provided that they do not occur over a large area for too long).

It is also accepted that elephant populations which are confined but not managed, will increase in number to a level where negative impacts on the system's biodiversity will result.

In recognising the above three principles, the following corollaries have to be considered:

- to maintain an elephant population at a high level will require the culling and/or translocation of a larger number of individuals than when maintaining it at a lower level (this may have moral or ethical considerations);

- the reduction of an elephant population from a high level to a lower level will require the culling and/or translocation of a larger number of individuals than maintaining it at a lower level (this may have moral or ethical considerations);

- wherever possible, management of the elephant population should be conducted by non-lethal means (translocation, contraception, etc.) but that where these methods prove inadequate, culling must remain an option for use.

- When culling is necessary, only the most humane method available should be used.

\section{Options for controlling elephant numbers other than culling}

When or wherever elephant population control is considered necessary, the priority will always be to do so by non-lethal means. It is stressed that these options are not likely to fulfil the requirements needed to manage the KNP elephant population successfully. Where these options are not feasible, culling is currently the only practical option available to do so. 


\section{Translocation (live transfer)}

Before the development of methods to translocate adult elephants, juvenile animals were captured at culling operations for translocation. Up to 1994,1339 juveniles were translocated in this way to other conservation areas. By 1994, methods enabling the live transfer of adult elephants had been developed and since then, 300 elephants in family units have also been translocated. With the advent of this technology, it is now believed that the translocation of juvenile animals is inhumane and therefore undesirable. This latter option will no longer be practised-only animals in intact family units will be transferred live out of the KNP from now on.

Over the long term, the limited market for live animals will not provide the option of removing all excess elephants from the KNP through live transfer.

\section{Contraception}

The current state of contraception technology can not yet offer a satisfactory method of population control in elephants. At present there are two methods of preventing conceptions being researched in the KNP which were reviewed by Whyte \& Grobler (1997). These are the so called "immuno-contraception" in which the animal's immune system is activated to prevent conception by vaccination (Kirkpatrick undated), and hormonal control by inserting slow-release oestradiol implants under the skin (Meyer et al. undated). Both of these projects are still at very early stages. Due to the costs and logistics of applying these methods, they have been shown by Whyte et al. (in press) to be unsuitable for use in large populations in large conservation areas.

\section{a. Immuno-contraception}

The immuno-contraception project has now been underway since October 1996 and will take several more years to complete. If shown to be successful, it would appear to offer some options for use in small popula- tions. One aspect of this project that has yet to be demonstrated is that the vaccine will not induce permanent damage to the ovaries of elephant cows, causing permanent sterility. If this should be the case, the method might be considered ethically unacceptable and therefore unlikely as an option for the future.

\section{b. Oestradiol implants}

This project has also been underway since October 1996 but monitoring of the treated animals has shown that the hormonal disturbances arising from the high levels of circulating oestrogen make the method ethically unacceptable in its present form. Treated cows are induced into a state of false oestrus and are therefore attractive to bulls. The constant attention of these bulls drives the cow away from her still dependant calf and from her family unit. Monitoring of these animals has suggested that this results in increased mortality of the calves. Unless these side effects can be satisfactorily overcome the method will not hold an option for either large or small populations.

Opposition to the contraception option has been voiced by adjacent communities as they hold the belief that sustainable utilisation of the population should be practised. However, the National Parks Board will continue to support research on contraception technology with the hope that it will ultimately provide an additional practical and affordable option for the control of the KNP (and other) elephant populations.

\section{Proposed new policy for the management of the KNP elephant population}

As with other aspects of the management of the KNP, the new elephant management policy will differ from the old one in that the elephant population will be managed according to measured impacts on biodiversity rather than on absolute numbers of elephants. Different management options will be practised in different zones and aspects of biodiversity will be monitored. The manage- 


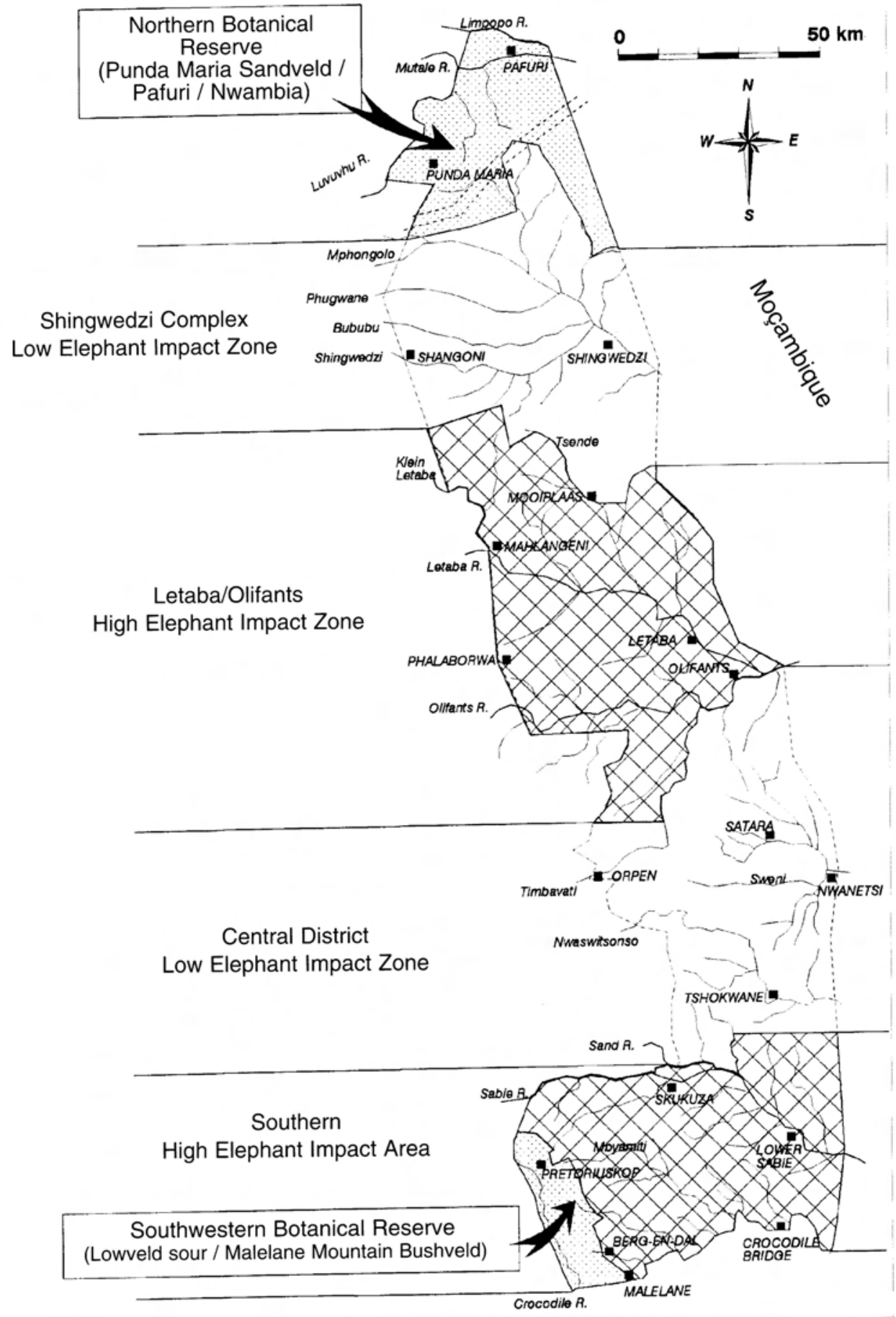

Fig. 2. Zonation of the Kruger National Park for elephant management. 
ment option will continue until there is clear evidence that the prevailing density of elephants is having a negative impact on some aspect of biodiversity which warrants concern. This point will be known as a "Threshold of Potential Concern".

Such TPCs are initially established at somewhat arbitrary levels on "best-availableknowledge-and-experience". It is absolutely necessary when deciding to use such TPCs that it must be accompanied by monitoring at appropriate intervals, and that there must be considerable understanding of the factors causing change in the parameter being monitored.

TPCs have the advantage that management has definite proactive objectives or parameters within which to manage a system, in contrast to previous practices where reactively managed events or processes to minimise or avoid crises. Nevertheless, TPCs should be constantly challenged as to their appropriateness or validity, and adaptively modified with increasing knowledge and experience.

The appropriate TPCs for the management of the KNP elephant population have been set "widely" which will allow for considerable fluctuation in the populations of the respective management zones. The TPCs for elephant are given (in their current form) at the end of this elephant management policy proposal.

\section{A zoning system for management of ele- phant impact}

The KNP will be divided into six zones which will receive different treatments in terms of the management of their respective elephant populations (see Fig. 2). These zones are: two botanical reserves; two highdensity elephant zones; and two low-density elephant zones.

In the high-density elephant zones the population will be allowed to increase (no culling or live removals) until there are indications that one or more of the thresholds of potential concern (TPCs) have been reached or exceeded. It is expected that the elephant population of these zones will increase at around $7 \%$ per year (Whyte in prep.). In the low-density elephant zones the population will be decreased (through culling or live removals) until there are indications that low densities of elephants have induced change to a point that one or more of the TPCs have been reached or exceeded. This decrease will be achieved through the reduction of the populations of these zones by $7 \%$ per year. As the numbers of elephants in these zones are also expected to increase at $7 \%$ per year, it will mean the setting of a removal quota of $14 \%$ of the total recorded during the census to achieve a $7 \%$ reduction. In the Botanical Reserves (and initially in the Southern Highdensity Zone), medium densities are to be maintained. "Medium density" is here considered to be the density prescribed in the previous Masterplan (Joubert 1986) which was one elephant per $2.86 \mathrm{~km}^{2}$ (7 000 elephants in $20000 \mathrm{~km}^{2}$ ). Should one or more of the defined TPCs be reached or exceeded in these zones, then elephant numbers should be systematically reduced to negate this.

It is hoped that it will prove feasible for the management actions being applied in the high and low-density zones to be alternated so that once a TPC has been reached or exceeded in any of the management zones, the alternate action will then be applied. High-density areas can then be treated as low-density zones and their populations systematically reduced while the elephant populations of the low-density zones can simultaneously be allowed to increase. While it is accepted in principle that this managed form of flux in the elephant population may prove to be beneficial and contribute to the maintenance of biodiversity in the KNP, it is felt that this should be demonstrated before it becomes permanently embodied in the elephant management policy, as there is some concern that increased elephant densities in the zones allocated may affect biodiversity in a way that is not reversible by a subsequent reduction in the elephant population. 
A theoretical example may be that a high elephant population may induce a decline in the population of some tree species which may then not be able to recover under the pressure of even a much lower elephant population. A more cautious approach will be followed-once the effects of an increased elephant population are better understood, this part of the policy should be reviewed.

\section{Elephant management zones}

The boundaries of the respective elephant management zones have been defined so as to roughly conform to the known boundaries of elephant clans as defined by Whyte (In prep). This is to allow meaningful elephant management without disrupting the natural home ranges of these clans. The boundaries have also been defined so as to ensure that the four major zones (excluding the botanical reserves) are of a similar size.

\section{Northern botanical reserve (Sandveld ) Pafuri / Nwambia)}

\section{a. Rationale}

This area encompasses some of the vegetation types/landscapes which it is felt should not be placed at risk of excessive elephant impacts. The landscapes and vegetation types concerned are the Colophospermum mopane forest (Landscape 15 (Gertenbach 1983)), the Adansonia digitata/Sterculia rogersii area and the Nwambia sandveld communities. Whyte et al. (1996) have suggested that elephants may be partially responsible for a decline in the baobab population of this area.

\section{b. Boundaries}

The southern boundary extends from Dothole eastward along the Manangananga Firebreak to Magamba; then northward along the Shingwedzi/ Pafuri tarred road (HI-8) to Klopperfontein; then eastward along the Masokosa road to Masokosa Pan; then southward along the military service road; then turning eastward to the Eastern boundary along the firebreak between Burning blocks 41 and 42 . The other boundaries are constituted by the eastern, northern and western boundaries of the KNP. According to the KNP GIS system, the area of this zone is $1552 \mathrm{~km}^{2}$.

\section{c. Elephant management}

Elephant densities are to be initially maintained at a density of one elephant per $2.86 \mathrm{~km}^{2}$. These densities will be monitored annually during aerial censuses and elephant movements in and out of the area will be monitored through the ongoing movement study using radio-collared animals. The number of elephants in the area should not exceed 550. However, should one or more of the defined TPCs be reached or exceeded, then elephant numbers should be systematically reduced (or increased) to negate this, as understanding indicates.

\section{South-western botanical reserve (Lowveld Sour/Malelane Mountain Bushveld)}

\section{a. Rationale}

This area also encompasses some of the vegetation types/landscapes which it is felt should not be placed at risk of excessive elephant impacts. These are the Lowveld Sourand Malelane Mountain Bushveld landscapes (Landscapes 1 and 2).

\section{b. Boundaries}

The northern and eastern boundaries of this zone extend from Thlothloma on the western boundary eastward along the northern and eastern boundaries of Burning block 35 ; then along the northern and eastern boundaries of Burning block 57; then southward along the eastern boundary of Burning block 90; then following the western boundary of Burning blocks 103 and 87 as far south as Malelane Restcamp. The western boundary of the zone follows the western boundary of the KNP from Thlothloma southward to Sigaas mouth, and the southern boundary of the zone is the Crocodile River between Sigaas 


\section{a. Rationale}

Although this area has been zoned as a high elephant impact zone, there would be some clear advantages to zoning it in stead as a low-impact zone, and the "Central District High-impact Zone" as a low-impact zone, though this still requires some debate. The advantages are that it would create a single core high-impact zone in the middle of KNP, and there will be no "hard edge" between the high-impact zones and the botanical reserves. This would afford the botanical reserves a greater degree of protection. The two back-to-back high-impact zones could still be treated as separate zones after TPCs have been exceeded, and the decision has been taken to reverse the elephant management actions. This decision has not yet been taken, but if this option is chosen, it will not significantly affect the basic new policy as approved. There would still be four zones, two high- and two low-impact zones whose elephant management strategies could be alternated and reversed.

It is considered strategically unwise to allow elephant numbers to concurrently increase unchecked in two zones of the KNP, as this may lead to both areas simultaneously reaching a state in which TPCs have been exceeded due to high densities of elephants. Simultaneous reduction of elephant numbers in two areas may prove logistically unfeasible. As it may yet be shown that changes induced by impacts of high densities of elephants may not be reversible through subsequent reduction of their numbers, a five year time lapse between the two high-density zones is considered prudent. Elephant numbers will therefore be held at the current status quo (one elephant per $2.86 \mathrm{~km}^{2}$ ) for another five years before allowing them to increase. Thereafter, as with the LetabalOlifants high density zone, no reduction of elephant numbers will occur through either culling or live removal.

\section{b. Boundaries}

The western boundary of this zone is a common boundary between the high-density elephant zone and the South-western Botanical Reserve. The southern boundary extends eastward along the Crocodile River from Malelane to the Mozambique Border; the eastern border of the zone then extends northward along the Mozambique border to the Rietpan Firebreak; the Northern border extends along the Rietpan Firebreak westwards to the Nwatindlopfu River; then southward along this river to its confluence with the Sabie River; then westwards along the Sabie River to the KNP's western boundary. According to the KNP GIS system, the area of this zone is $3436 \mathrm{~km}^{2}$.

\section{c. Elephant management}

Until the mentioned five year delay has elapsed, the number of elephants in the zone should not be allowed to exceed 1220. After the five year delay period has elapsed, no reduction of elephant numbers will occur through either culling or live removal. Numbers are expected to increase at a mean rate of around $7 \%$ per year. Elephant numbers will be allowed to increase until one or more of the defined TPCs are reached or exceeded and then systematically reduced so as to induce the desired flux (unless experience gained in the Letaba/Olifants High-density Elephant Zone should indicate a different course of management action).

Monitoring of specific indicator components of biodiversity will occur to determine the impacts of increasing elephant density. The increase will be allowed to continue until one or more of the defined TPCs has been reached or exceeded. Appropriate management actions will then be considered (see under "Elephant management policy" above).

Elephant densities will be monitored annually during aerial censuses and elephant movements in and out of the area will be monitored through the ongoing movement study using radio-collared animals. 
Shingwedzi Complex low elephant impact zone

\section{a. Rationale}

As with an increasing elephant population, it is expected that declining elephant numbers will also adversely affect biodiversity as the positive benefits of elephant impacts on heterogeneity are reduced. Elephant numbers will be systematically reduced at a rate of approximately $7 \%$ per year. By reducing the number of elephants at a consistent rate of $7 \%$ per year the actual number to be removed gradually declines each year so that the effects of the decline will diminish gradually.

By reducing numbers in two zones, the total number of elephants in the KNP will not be greatly influenced by the increases in the other two zones, keeping the total population at a level which would not exceed our management capabilities should the high density zones prove to be detrimental to biodiversity.

The reduced elephant density in this zone will also act as a buffer between the Letaba/Olifants high density zone and the Northern Botanical Reserve.

\section{b. Boundaries}

The northern boundary of this zone is a common boundary with the Northern Botanical Zone's southern boundary; the southern boundary of this zone is a common boundary with the Letaba/Olifants high density zone's northern boundary. The eastern and western boundaries of the zone follow the eastern and western boundaries of the KNP. According to the KNP GIS system, the area of this zone is $4026 \mathrm{~km}^{2}$.

\section{c. Elephant management}

Elephant densities will be reduced in this zone by $7 \%$ per year until one or more of the defined TPCs has been reached or exceeded. Appropriate management actions will then be considered (see "Elephant management policy" above). Elephant densities will be monitored annually during aerial censuses. Quotas for culling or live removals will be determined after the annual census result has become available. Elephant movements in and out of the area will be monitored through the ongoing movement study using radiocollared animals.

\section{Central District low elephant impact zone}

\section{a. Rationale}

As with the Shingwedzi complex low-density elephant zone, elephant numbers will be systematically reduced at a rate of approximately $7 \%$ per year. By reducing the number of elephants at a consistent rate of $7 \%$ per year the actual number to be removed gradually declines each year so that the effects of the decline will diminish gradually.

By reducing numbers in two zones, the total number of elephants in the KNP will not be greatly influenced by the increases in the other two zones, keeping the total population at a manageable level.

\section{b. Boundaries}

The northern boundary of this zone is a common boundary with the Letaba/Olifants high density zone's southern boundary; the southern boundary of this zone is a common boundary with the Southern high density zone's northern boundary. The eastern and western boundaries of the zone follow the eastern and western boundaries of the KNP. According to the KNP GIS system, the area of this zone is $4149 \mathrm{~km}^{2}$.

\section{c. Elephant management}

Elephant densities will be reduced in this zone by $7 \%$ per year until one or more of the defined TPCs has been reached or exceeded. Appropriate management actions will then be considered (see "Elephant management policy" above). Elephant densities will be monitored annually during aerial censuses. Quotas for culling or live removals will be determined after the annual census result has 
Table 2

Thresholds of potential concern for elephants in the Kruger National Park

\begin{tabular}{ll}
\multicolumn{1}{c}{ Criterion } & \multicolumn{1}{c}{ Measure } \\
\hline $\begin{array}{l}\text { Vegetation heterogeneity at } \\
\text { coarse (mega) scale. }\end{array}$ & $\begin{array}{l}\text { Coverage }\left(\mathrm{km}^{2}\right) \text { of land- } \\
\text { scape scale units (e.g. } \\
\text { Gertenbach) determined } \\
\text { every 5 years. Result com- } \\
\text { pared to any previous time, } \\
\text { including historical. }\end{array}$
\end{tabular}

Vegetation structure at community scale using size classes for a range of indicator woody species.

Woody canopy cover at community scale.

Rare, sensitive or characteristic (of the Lowveld) woody species (only in relation to elephant utilisation - short list).

Birds as surrogates for structural riparian health.
Assume, e.g. 4 size classes. Then homogenisation is $90 \%$ dominance of any 2 size classes.

$\%$ woody (within stratified landscapes, e.g. riparian) as determined from aerial photographs, done every 3 years.

Population size and structure fed into pv model.

Presence of species using reedbeds, mudflats, litter, lower stratum, middle stratum, upper stratum.

\section{Within-zone TPC}

$80 \%$ change (cumulative) in the area of any landscape scale classification unit. $30 \%$ change (cumulative) in the area of any landscape scale classification unit.

$80 \%$ of all plots homogenous. Sensitive landscapes examined independently as well.

$80 \%$ decline in canopy cover; specified increase with asymptote (see graph).
$30 \%$ of all plots homogenous. Sensitive landscapes examined independently as well.

$30 \%$ decline in canopy cover; specified increase with asymptote (see graph).
$99 \%$ probability of population persistence for next 100 years.
None, prepared to accept local loss or definite trend towards local loss of certain species (provided same species not declining seriously in lo/hi zones at the same time. i.e. species should NOT survive only in botanical reserves.)

Because all perennial rivers are in or border on current high elephant areas, there is need for an in-zone TPC when species from any category are no longer represented on any particular perennial river.

Recolonisation thus assumed between zones.

See above.

Frugivores, gramnivores, insectivores (bark foragers, hawkers, leaf-gleaners), piscivores, raptors, nectarivores, frugivores, gramnivores, etc. functional cl representatives in riparian corridors (what about outside riparian corridors as well, with own TPC's?)

Invertebrate functional class representation.
Ground and grass insects and spiders, tree dwelling insects and spiders, dung beetles, termites (harvester and macrotermes mounds), millipedes, pollinators.
When any class disappears from any zone (see proviso in whole-park TPC). Assumes recolonisation.
Provided there are not serious concomitant decline of same classes in alternate zones.
Perennial rivers dealt with as within-zones issue per river; for seasonal rivers there will be a whole-park TPC, namely : when species from any category no longer represented in park as a whole - recolonisation from perennials rivers assumed.

See above.
RS classification - bare ground index.
When affected area > unaffected area (ie. index $>50 \%$ ) or when affected area $<5 \%$ (latter to guarantee some eroded habitat in any zone).
When aggregated wholepark bare ground index less than $2.5 \%$ or $>25 \%$. 
become available. Elephant movements in and out of the area will be monitored through the ongoing movement study using radiocollared animals.

\section{Thresholds for potential concern relevant to elephant impact}

Table 2 is directed at high and low elephant zones, not at botanical reserves which need their own specific TPCs geared at plant community viability and optimum chance for rare species survival. The so-called "wholepark" measures given here thus refer to the whole park excluding the botanical reserves.

ANY ONE TPC reached is meant to act as a significant warning sign on its own, and although evaluated in overall context with the rest, must be taken seriously in its own right.

The TPCs given here presuppose that any action then taken will significantly alter the predisposing environment which allowed that TPC to be reached. If at some stage in the future it is believed that a very high density elephant population has evoked a TPC, this is of particular importance in the manner that the populations are to be reduced. While both initial fast reduction (say bringing one compartment down to by $2 / 3$ of the density within a few years, then slowly thereafter) and slow reduction (bringing the high density down by say $7 \%$ a year net reduction in growth rate after such a very high density phase) have been modelled, the TPCs given here presuppose the fast removal. If slow removal is chosen, it will be important to tone down the TPCs somewhat to take into account the continued almost-as-high impact which will follow for many years after the peak is reached.

The relationship between the percentages given for within-zone and for the whole park may at first seem strange, given that the areas of the high and low zones are approximately equal (i.e., one might expect never to reach the whole-park TPCs). However, it is possible that only one of the two high (or for that matter low) zones may show severe changes, justifying the operational use of $30 \%$ (i.e., less than half of the $80 \%$ ) as a TPC.

Although this list focuses on TPCs believed to be directly related to elephant and discussed as such at the biodiversity meeting, other categories of TPCs (e.g., riparian health) may be exceeded due to elephant influence. These obviously qualify as valid TPCs in their own right.

\section{Decision-making}

Recommendations to the KNP Director as to appropriate actions for the management of elephants in the respective zones should be made by the Standing Committee for Nature Conservation. The Standing Committee should co-opt appropriate senior management and research staff to appraise the results of the respective biodiversity monitoring projects and the annual elephant census results. Such appraisal should be done on an annual basis.

\section{Acknowledgements}

We thank the many people who in various ways contributed to the formulation of this policy. Although individual acknowlegement would be extremely difficult, many of these contributers could would be justified in taking full ownership. The role of the authors was merely to consolidate and write up this article.

\section{References}

Behnke, R.H., I. Scoones i. C. Kerven. 1993. Range ecology at disequiiibrium. London: Overseas Development Institute.

Brynard, A.M. 1965. Ekologiese Gebiede in die Krugerwildtuin. Proceedings of Symposium on Problems of Over-protection of Wildlife. Typescript. Skukuza, National Parks Board.

BUECHNER, H.K., I.O. BuSS \& W.M. LONGHURST. 1963. Numbers and migration of elephants in Murchison Falls National Park, Uganda. Journal of Wildlife Management 27(1): 36-53. 
Christensen, N.L. 1997. Managing for heterogeneity and complexity on dynamic landscapes. Pp. 167-186. In: PiCKetT, S.T.A., R.S. OSTFELD, M. SHACHAK \& G.E. LiKENS (eds.). The ecological basis of conservation. New York: Chapman.

Cumming, D.H.M., M.B. Fenton, I.L. Rautenbach, R.D. Taylor, G.S. Cumming, M.S. Cumming, J.M. Dunlop, G.A. Ford, M.D. Hovorka, D.S. Johnston, M. Kalcounis, Z. Mahlangu \& C.V.R. PORTfors. 1997. Elephants, woodlands and biodiversity in southern Africa. South African Journal of Science 93: 231-236.

Dublin, Holly, T. 1995. Vegetation dynamics in the Serengeti-Mara ecosystem: The role of elephant, fire and other factors. In: Sinclair, A.R.E. \& P. ARCESE. 1995. Serengeti II. University of Chicago: Chicago Press.

FAIRALL, N. 1965. Die invloed van vrugbaarheid en natuurlike beheermeganismes in bevolkingsgroei. Proceedings of symposium on problems of over-protection of wildlife. Typescript. Skukuza, National Parks Board.

Fiedler, P.L., P.S. White \& R.A. Leidy. 1997. The paradigm shift in ecology and its implications for conservation. Pp. 83-92. In: PICKETT, S.T.A., R.S. Ostfeld, M. ShachaK \& G.E. Likens (eds.). The ecological basis of conservation. New York: Chapman.

KirKPATRICK, J.F. Undated. African Elephant Conservation Act Grant Program: Proposal Application. Non-lethal control of African elephant (Loxodonta africana) populations by means of immunocontraception. Typescript submitted to National Parks Board.

GertenbaCH, W.P.D. 1983. Landscapes of the Kruger National Park. Koedoe 26: 9-122.

Glover, J. 1963. The elephant problem at Tsavo. East Africa Wildlife Journal 1: 30-38.

Hall-Martin, A.J. \& P. Novellie. 1996. Review of the Management Policy of the Kruger National Park: Discussion Document for the facilitation of participation in the review process. Typescript. Skukuza, National Parks Board.

Hall-Martin, A.J., I.J. Whyte \& P.C. Viljoen. 1987. Census results and culling quotas for the large herbivore species in the Kruger National Park. Typescript. Skukuza, National Parks Board.

Holling, C.S. 1995. What Barriers? What Bridges? Pp. 3-34. In: Gunderson, L.H., C.S. Holling, \& S.S. Light. (eds.). Barriers and bridges to the renewal of ecosystems and institutions. New York: Columbia University Press.

JoubERT, S.C.J. 1980. Lugsensusresultate vir grootwildsoorte in die Nasionale Krugerwildtuin
1980. Typescript. Skukuza, National Parks Board.

JouBERT, S.C.J. 1981. Census results for the large herbivore species in the Kruger National Park, 1981. Typescript. Skukuza, National Parks Board.

JouberT, S.C.J. 1982. Census results for the large herbivore species in the Kruger National Park, 1982. Typescript. Skukuza, National Parks Board.

JouberT, S.C.J. 1983. Census results for the large herbivore species in the Kruger National Park, 1983. Typescript. Skukuza, National Parks Board.

JouberT, S.C.J. 1984. Census results for the large herbivore species in the Kruger National Park, 1984. Typescript. Skukuza, National Parks Board.

JouberT, S.C.J. 1985. Census results for the large herbivore species in the Kruger National Park, 1985. Typescript. Skukuza, National Parks Board.

JOUBERT, S.C.J. 1986. Masterplan for the management of the Kruger National Park. Unpublished internal memorandum. Skukuza, National Parks Board.

Joubert, S.C.J., A.J. Hall-Martin \& I.J. Whyte. 1986. Census results for the large herbivore species in the Kruger National Park. Typescript. Skukuza, National Parks Board.

Joubert, S.C.J. \& U. DE V. PienaAR. 1971. 'n Lugsensus van olifante, buffels en ander grootwild in die Krugerwildtuin gedurende Augustus en September 1971, en die implikasies daarvan op die onderskeie uitdun-programme. Typescript. Skukuza, National Parks Board.

Joubert, S.C.J. \& U. DE V. PienaAr. 1972. 'n Lugsensus van olifante, buffels en ander grootwild in die Krugerwildtuin gedurende Augustus en September 1972, en die implikasies daarvan op die onderskeie uitdun-programme. Typescript. Skukuza, National Parks Board.

Joubert, S.C.J. \& U. DE V. PIEnAar. 1973. 'n Lugsensus van olifante, buffels en ander grootwild in die Krugerwildtuin gedurende Augustus en September 1973, en die implikasies daarvan op die onderskeie uitdun-programme. Typescript. Skukuza, National Parks Board.

JouberT, S.C.J. \& U. DE V. PIEnAar. 1974. 'n Lugsensus van olifante, buffels en ander grootwild in die Krugerwildtuin gedurende 26 Augustus tot 12 September 1974, en die implikasies daarvan op die onderskeie uitdun-programme. Typescript. Skukuza, National Parks Board. 
JouberT, S.C.J. \& U. DE V. PienaAr. 1975. 'n Lugsensus van olifante, buffels en ander grootwild in die Krugerwildtuin gedurende 25 Augustus tot 12 September 1975, en die implikasies daarvan op die onderskeie uitdun-programme. Typescript. Skukuza, National Parks Board.

Joubert, S.C.J. \& U. DE V. Pienaar. 1977. 'n Lugsensus van olifante, buffels en ander grootwildsoorte in die Krugerwildtuin gedurende Augustus en September 1977, en die implikasies daarvan op die bestuur van die grootwild-populasies. Typescript. Skukuza, National Parks Board.

Joubert, S.C.J. \& U. DE V. PienaAr. 1978. 'n Lugsensus van olifante, buffels en ander grootwildsoorte in die Krugerwildtuin gedurende Augustus en September 1978, en die implikasies daarvan op die bestuur van die grootwild-populasies. Typescript. Skukuza, National Parks Board.

Joubert, S.C.J., U. DE V. Pienaar, J.J. Kloppers \& D.J. ACKERMAN. 1976. 'n Lugsensus van olifante, buffels en ander groot-wild in die Krugerwildtuin gedurende 19 Julie tot 6 Augustus 1976, en die implikasies daarvan op die bestuur van die grootwild-populasies. Typescript. Skukuza, National Parks Board.

KNOBEL, R. 1965. Algemene beginsels van natuurbewaring. Proceedings of symposium on problems of over-protection of wildlife. Typescript. Skukuza, National Parks Board.

LABuSChaGNE, R.J. 1965. Newe produkte: behandeling en afset. Proceedings of symposium on problems of over-protection of wildlife. Typescript. Skukuza, National Parks Board.

Meyer, H.H.D., S. Quandt, F. Goritz, T. HildebrandT \& R.R. Hofmann. Undated. Contraception in the African elephant (Loxodonta africana) as a possible part of future elephant management policy. Typescript submitted to National Parks Board.

National Parks BoARd of Trustees. 1966. Minutes of the meeting of 22 March 1966. Typescript. Skukuza, National Parks Board.

PienaAR, U. DE V. 1960. Die status van olifante in die Suidelike Distrik van die Nasionale Krugerwildtuin. Typescript. Skukuza, National Parks Board.

PienaAR, U. DE V. 1963. Large mammals of the Kruger National Park - their distribution and present-day status. Koedoe 6: 1-137.

PienaAR, U. DE V. 1967. 'n Lugsensus van olifante en ander grootwild in die hele Krugerwildtuin gedurende September 1967. Typescript. Skukuza, National Parks Board.
PIENAAR, U. DE V. 1968. 'n Lugsensus van olifante en ander grootwild (uitgesonderd buffels) in die hele Krugerwildtuin gedurende 5 - 21 September 1968. Typescript. Skukuza, National Parks Board.

PienaAR, U. DE V. 1969. 'n Lugsensus van olifante en buffels in die Nasionale Krugerwildtuin gedurende 25 Augustus - 6 September, 1969. Typescript. Skukuza, National Parks Board.

PIENAAR, U. DE V. 1996. Kommentaar op die besprekings dokument vir die fasilitering van deelname aan die hersienings proses - "Review of the Management Policy of the Kruger National Park" deur A. Hall-Martin \& P. Novellie. Unpublished manuscript. Skukuza, National Parks Board.

Pienaar, U. DE V., P. Van WyK \& N. Fairall. 1966. An aerial census of elephant and buffalo in the Kruger National Park and the implications thereof on intended management schemes. Koedoe 9: 40-107.

PienaAr, U. DE V. \& P. VAN WYK. 1970. 'n Lugsensus van olifante, buffels en ander grootwild in die Krugerwildtuin gedurende 10-24 Augustus, 1970, en die implikasies daarvan op die onderskeie uitdun-programme. Typescript. Skukuza, National Parks Board.

RaAd van Kuratore vir Nasionale Parke. 1967. Een-en-veertigste Jaar-verslag. Pretoria: National Parks Board.

SAndenbergh, J.A.B. 1946. Kruger National Park, Warden's Annual Report 1946. Typescript. Skukuza, National Parks Board.

South African National Parks. 1998. Minutes Public presentation of the revised Kruger National Park elephant management proposal. Typescript. Skukuza, National Parks Board.

Stevenson-Hamilton, J. 1903a. Report on Singwitsi Game Reserve. Transvaal Administration Reports for 1903. Typescript. Skukuza, National Parks Board.

Stevenson-Hamilton, J. 1903b. Game preservation. Transvaal Administration Reports for 1903. Typescript. Skukuza, National Parks Board.

Stevenson-Hamilton, J. 1905. Report on the Government Game Reserves for the year ended 30th June 1905. Typescript. Skukuza, National Parks Board.

Stevenson-Hamilton, J. 1909b. Report on Government Game Reserves. Annual Report 1908-9. Typescript. Skukuza, National Parks Board.

Stevenson-Hamilton, J. 1925. Extracts from the annual report of the Transvaal Game Reserves. 1925. Typescript. Skukuza, National Parks Board. 
Stevenson-Hamilton, J. 1932. Kruger National Park, Warden's Annual Report 1932. Typescript. Skukuza, National Parks Board.

Stevenson-Hamilton, J. 1933. Kruger National Park, Warden's Annual Report 1933. Typescript. Skukuza, National Parks Board.

Stevenson-Hamilton, J. 1936. Kruger National Park, Warden's Annual Report 1936. Typescript. Skukuza, National Parks Board.

Stevenson-Hamilton, J. 1937. Kruger National Park, Warden's Annual Report 1937. Typescript. Skukuza, National Parks Board.

STEYN, L.B. 1942. Extract from diary, 21 May, 1942. National Parks Board Archives. Skukuza, National Parks Board.

STEYN, L.B. 1958. Jaarverslag van die Opsiener: Nasionale Krugerwildtuin vir die tydperk 1 April 1957 tot 31 Maart 1958. Typescript. Skukuza, National Parks Board.

Van Der Merwe, N.J. 1965. Publisiteit. Proceedings of Symposium on Problems of Over-protection of Wildlife. Typescript. Skukuza, National Parks Board.

VAN Niekerk. J. 1965. Kontrole deur middel van siektes en parasiete. Proceedings of symposium on problems of over-protection of wildlife. Typescript. Skukuza, National Parks Board.

VAN WYK. P. 1965. Weidingspotensiaal, -verbruik en -beheer in die Nasionale Krugerwildtuin. Proceedings of symposium on problems of overprotection of wildlife. Typescript. Skukuza. National Parks Board.

VAN WYK, P. \& N. FAIRALl. 1969. The influence of the African elephant on the vegetation of the Kruger National Park. Koedoe 12: 57-89.

Western. D. \& H. Gichohi. 1989. Segregation effects and the impoverishment of savanna parks: the case for ecosystem viability analysis. African Journal of Ecology 31: 269-281.

Whyte, I.J. 1998. Census results for elephant and buffalo in the Kruger National Park in 1997 and 1998. Scientific Report 8/98. Skukuza, National Parks Board.

WhYTE. I.J. In prep. Population biology and movements of elephant Loxodonta africana (Blumenbach 1797) in the Kruger National Park. Ph.D. thesis. University of Pretoria, Pretoria.

Whyte. I.J. \& H.C. BıgGS. 1997. Report on a workshop held at Skukuza on 30 October 1996 to discuss options for the management of the Kruger National Park elephant population. Scientific Report 2/97. Skukuza, National Parks Board.
Whyte, I.J. \& D.G. Grobler. 1997. The current status of elephant contraception research in the Kruger National Park. Scientific Report 13/97. Skukuza, National Parks Board.

Whyte, I.J., P.J. Nel, T.M. Steyn \& N.G. Whyte. 1996. Baobabs and elephants in the Kruger National Park; Preliminary report. Scientific Report 5/96. Skukuza, National Parks Board.

Whyte, I.J., R.J. VAN AARde \& S.L. PIMM. 1998. Managing the elephants of Kruger National Park. Animal Conservation 1(2): 77-83.

Whyte, I.J. \& P.C. Viljoen. 1988. Census results and culling quotas for the large herbivore species in the Kruger National Park in 1988 Typescript. Skukuza, National Parks Board.

Whyte, I.J. \& P.C. VILJoEN. 1989. Census results and culling quotas for the large herbivore species in the Kruger National Park in 1989 Typescript. Skukuza, National Parks Board.

Whyte, I.J. \& C.A. Wood. 1992. Census results for elephant and buffalo in the Kruger National Park in 1991 and culling quotas for the 1991/92 culling year. Typescript. Skukuza, National Parks Board.

Whyte, I.J. \& C.A. Wood. 1993. Census results for elephant and buffalo in the Kruger National Park in 1992 and culling quotas for the 1992/93 culling year. Scientific Report 3/93. Skukuza. National Parks Board.

Whyte, I.J. \& C.A. Wood. 1994(a). Census results for elephant and buffalo in the Kruger National Park in 1993 and culling quotas for the 1993/94 culling year. Scientific Report 3/94. Skukuza. National Parks Board.

Whyte, I.J. \& C.A. WoOd. 1994(b). Census results for elephant and buffalo in the Kruger National Park in 1994 and culling quotas for the 1994/95 culling year. Scientific Report 14/94. Skukuza. National Parks Board.

Whyte, I.J. \& C.A. WoOD. 1995. Census results for elephant and buffalo in the Kruger National Park in 1995. Scientific Report 14/95. Skukuza. National Parks Board.

Whyte, I.J. \& C.A. Wood. 1996. Census results for elephant and buffalo in the Kruger National Park in 1996. Scientific Report 20/96. Skukuza. National Parks Board.

WIENS, A.W. 1997. The emerging role of patchiness in conservation biology. Pp. 93-107. In: PICKETT. S.T.A., R.S. Ostfeld, M. Shachak \& G.E. LIKENS (eds.). The ecological basis of conservation. New York: Chapman. 